\title{
Ocular colobomata, cardiac defect, and other anomalies: a study of seven cases including two sibs*
}

\author{
C. K. HO, R. L. KAUFMAN, and S. M. PODOS \\ From the Departments of Pediatrics, Medicine and Ophthalmology, Washington University School of Medicine and \\ St Louis Children's Hospital, St Louis, Missouri 63110, USA
}

\begin{abstract}
Summary. An association of ocular colobomata and congenital heart disease was observed in seven patients. Two of these were maternal half sisters whose mother also had ocular colobomata. All the patients had normal karyotypes. There was a high incidence of other associated abnormalities involving the central nervous, skeletal, and urogenital systems. Discovery of an ocular coloboma should alert the clinician to search for other abnormalities.
\end{abstract}

Colobomatous malformations of the eye may be associated with chromosomal abnormalities (François, 1968a), maternal exposure to teratogenic substances during early pregnancy (Cullen, 1964), and Mendelian disorders (Waardenburg et al, 1961), or they may occur without apparent cause. The majority of ocular colobomata are situated inferonasally. Such colobomata are called typical. If situated elsewhere they are called atypical (DukeElder, 1940). Ocular colobomata may occur alone or in combination with a number of abnormalities of other organs (François, 1968b). In 1961, Angelman pointed out the association of ocular colobomata with congenital heart disease (Angelman, 1961). Such a combination of malformations may be seen in certain well-defined chromosomal syndromes, for example, 13 trisomy (Conen et al, 1966; Lee et al, 1966; Warkany et al, 1966), 13q(Allderdice et al, 1969; Orbeli et al, 1971), 13 ring (Allderdice et al, 1969; Orbeli et al, 1971; Bilchick et al, 1972), 18 trisomy (Weber et al, 1964; Warkany et al, 1966), and cat eye syndrome (Schachenmann et al, 1965; Freedom and Gerald, 1973). There remain cases who have normal karyotypes. These are usually sporadic (Edwards et al, 1961 ; Lele et al, 1965).

\footnotetext{
Received 8 July 1974.

* Presented in part at the annual meeting of the American Society of Human Genetics in Atlanta, Georgia, on October 27, 1973 (Kaufman et al, 1973).

Reprint requests to R.L.K.: Department of Pediatrics, St Louis Children's Hospital, 500 So. Kingshighway, St Louis, Missouri 63110, USA.
}

Clinical studies of seven patients (Table I) with ocular colobomata and congenital heart disease who had normal karyotypes in cultured blood lymphocytes comprise this report. Two of the patients are maternal half sisters.

\section{Case reports}

Case 1. A white female was born by breech presentation at term in February 1972. The pregnancy was complicated by diabetes mellitus at 2 months of gestation. The 29-year-old mother and 37-year-old father were not consanguineous. The birth weight was $2670 \mathrm{~g}$, birth length $46 \mathrm{~cm}$, and head circumference $34.5 \mathrm{~cm}$.

Examination revealed dolichocephaly, typical iris colobomata with normal fundi, bilateral cataracts, horizontal nystagmus, prominent bifid xyphoid process, and a heart murmur described as a grade IV/VI ejection murmur loudest at the base and transmitted to the back. Findings from radiological examinations and cardiac catheterization demonstrated tetralogy of Fallot with marked infundibular and valvular pulmonary stenosis, bicuspid pulmonary valve, a large ventricular septal defect, and a right aortic arch. An intravenous pyelogram showed pelvic ectopia of the right kidney. The patient expired at 7 weeks of age due to cardiac failure. Necropsy confirmed the abnormalities described above.

Case 2, the maternal half-sister of case 1, was born at term by breech presentation 14 months after her sister's birth. Her father was a 34-year-old normal white man. He was not consanguineous with the mother and was not related to the father of case 1 . Birth weight was $2870 \mathrm{~g}$ and birth length $47 \mathrm{~cm}$. The pregnancy was complicated by diabetes mellitus discovered in the sixth month 
PATIENTS* WITH OCULAR COLOBOMATA, CONGENITAL HEART DISEASES

\begin{tabular}{|c|c|c|c|c|}
\hline Case & Sex & Birth date & Eyes & Heart \\
\hline 1 & $\mathbf{F}$ & $\begin{array}{l}\text { Feb } 1972 \\
\text { (died Apr 1972)t }\end{array}$ & $\begin{array}{l}\text { Typical iris colobomata and cataracts, OU; } \\
\text { nystagmus }\end{array}$ & $\begin{array}{l}\text { Tetralogy of Fallot; bicuspid pulmonic } \\
\text { valve; right aortic arch } \neq\end{array}$ \\
\hline 2 & $\mathbf{F}$ & Apr 1973 & Typical iris colobomata and cataracts, OU & Probable ventricular septal defect** \\
\hline 3 & $\mathbf{M}$ & Mar 1956 & $\begin{array}{l}\text { Typical colobomata of iris, lens, retina, } \\
\text { choroid, OU; alternating oesotropia; } \\
\text { nystagmus; ptosis, OU }\end{array}$ & Atrial septal defect $\ddagger$, $+\dagger$ \\
\hline 4 & $\mathbf{M}$ & Aug 1959 & $\begin{array}{l}\text { Coloboma of optic disc at nasal side, OS; } \\
\text { nystagmus }\end{array}$ & $\begin{array}{l}\text { Coarctation of aorta; bicuspid aortic valve; } \\
\text { pulmonic valvular stenosis; coarctation of } \\
\text { main, right and left pulmonary } \\
\text { arteries } \neq,+t\end{array}$ \\
\hline 5 & $\mathbf{M}$ & $\begin{array}{l}\text { Dec } 1972 \\
\text { (died Nov 1973)t }\end{array}$ & $\begin{array}{l}\text { Typical colobomata of retina, choroid, OU; } \\
\text { microphthalmos, cataract, and coloboma of } \\
\text { optic disc, OD }\end{array}$ & $\begin{array}{l}\text { Pulmonary atresia; right ventricular } \\
\text { hypoplasia; patent foramen ovale; large } \\
\text { patent ductus arteriosus } \ddagger \text {, } t+\end{array}$ \\
\hline 6 & $\mathbf{F}$ & $\begin{array}{l}\text { Mar } 1970 \\
\text { (died Nov 1972)t }\end{array}$ & $\begin{array}{l}\text { Colobomata of retina, choroid at posterior } \\
\text { pole, OU; microphthalmos, OD }\end{array}$ & $\begin{array}{l}\text { Double outlet right ventricle; pulmonary } \\
\text { stenosis; ventricular septal defect; right } \\
\text { ventricular hypertrophy }\end{array}$ \\
\hline 7 & $\mathbf{M}$ & Oct 1966 & $\begin{array}{l}\text { Typical coloboma of retina, choroid, OD; } \\
\text { blepharophimosis, ptosis, OU; alternating } \\
\text { exotropia, epicanthal folds, anti-mongoloid } \\
\text { slant, hypertelorism }\end{array}$ & $\begin{array}{l}\text { Ligamentum arteriosum connected to } \\
\text { retro-oesophageal left subclavian artery } \\
\text { (these and right aortic arch formed a } \\
\text { vascular ring) } \neq,+t\end{array}$ \\
\hline
\end{tabular}

* All had normal karyotypes from cultured blood lymphocytes. Patients 2 and 7 were studied with Giemsa and fluorescence banding tợhs niques; others with Giemsa staining without banding.

* Necropsy performed.

¥ Cardiac catheterization performed.

t† Cardiac surgery performed.

of gestation, which was treated with chlorpropamide* for 1 month before delivery.

The infant had prominent frontal bossing, anteverted nostrils, typical iris colobomata with normal fundi, bilateral congenital cataracts, and a grade III/VI systolic ejection murmur located at the left sternal border. Radiographs showed mild left atrial enlargement, compatible with a small left-to-right shunt, most likely a ventricular septal defect. Cardiac catheterization has not been performed.

The mother of case 1 and case 2 had typical iris colobomata. Cataracts were found at 3 years of age and glaucoma at 24 years of age. A heart murmur was noted at 16 years of age. At age 30 cardiac evaluation including physical examination, chest radiolograph, electrocardiogram, vectorcardiogram, and phonocardiogram revealed no evidence of congenital heart disease. A blood lymphocyte karyotype was normal. No other members of the family were known to have ocular colobomata or congenital heart disease.

Other cases which were sporadic are summarized in Table I.

\footnotetext{
* Trade name Diabinese (B)
}

\section{Discussion}

The incidence of coloboma of the iris in children, according to Bolk, is approximately 4 per 10000 (Bolk, 1904). The incidence of congenital heart disease is approximately 4 per 1000 live births (MacMahon et al, 1953). The probability of the two conditions occurring simultaneously in an individual purely by chance would be extremely small. Gardiner and Joseph (1968) reported that children with congenital heart disease had a high incidence of ocular abnormalities; among 85 patients they studied, one had coloboma of the choroid. Polani and Campbell (1955) studied 377 patients with congenital heart disease, one of whom was reported to have iris coloboma. Warkany (1971) noted several cases in which ocular colobomata and congenital heart disease occurred concurrently. In these reports karyotype results were not given, and detailed clinical descriptions are lacking. Lele et al (1965) reported five cases having coloboma of the iris; two individuals had congenital heart disease; 
AND ASSOCIATED ABNORMALITIES (PRESENT SERIES)

\begin{tabular}{|c|c|c|c|}
\hline \multicolumn{4}{|c|}{ Associated Abnormalities } \\
\hline Neurological & Skeletal & Urogenital & Others \\
\hline$?$ & $\begin{array}{l}\text { Bifid xyphoid process; } \\
\text { dolichocephaly }\end{array}$ & $\begin{array}{l}\text { Pelvic ectopia of the right } \\
\text { kidney }\end{array}$ & $\begin{array}{l}\text { Retarded growth and } \\
\text { development }\end{array}$ \\
\hline$?$ & - & - & - \\
\hline Mental retardation & $\begin{array}{l}\text { Pectus carinatum; kyphosis; } \\
\text { irregularity of vertebral } \\
\text { bodies; short fifth fingers }\end{array}$ & $\begin{array}{l}\text { Right kidney had double } \\
\text { collecting system with two } \\
\text { ureters }\end{array}$ & - \\
\hline Mental retardation; convulsions & $\begin{array}{l}\text { Short } 12 \text { th ribs; four lumbar } \\
\text { vertebrae; spina bifida } \\
\text { occulta S1; short left } 5 \text { th } \\
\text { finger }\end{array}$ & $\begin{array}{l}\text { Bilateral uretero-pelvic } \\
\text { junction obstruction; bilateral } \\
\text { extrarenal pelves; incomplete } \\
\text { medial rotation of the left } \\
\text { renal pelvis }\end{array}$ & - \\
\hline Convulsions & Only 11 rib pairs; no ribs on & Undescended testes & $\begin{array}{l}\text { Retarded growth and } \\
\text { development; scalp defect; } \\
\text { facial asymmetry; malformed } \\
\text { ears with preauricular pits } \\
\text { and skin tag }\end{array}$ \\
\hline $\begin{array}{l}\text { Mental retardation, microcephaly; } \\
\text { holoprosencephaly; agenesis of } \\
\text { corpus callosum; arrhinencephaly }\end{array}$ & $\begin{array}{l}\text { Butterfly vertebra; hemivertebra; } \\
\text { gibbus, small sternum; } \\
\text { shortened radii; absent } \\
\text { thumbs; oligodactyly and } \\
\text { syndactyly of feet; dislocated } \\
\text { hips }\end{array}$ & - & $\begin{array}{l}\text { Small for gestational age; } \\
\text { retarded growth and } \\
\text { development; micrognathia; } \\
\text { low-set ears; simian creases; } \\
\text { rectoperineal fistula; increased } \\
\text { chromosomal breaks (birth } \\
\text { control pills used in early } \\
\text { pregnancy) }\end{array}$ \\
\hline Mental retardation & $\begin{array}{l}\text { Asymmetrical skull; small sella } \\
\text { turcica; pectus excavatum; } \\
\text { kyphosis; bilateral coxa valga; } \\
\text { underdeveloped acetabula; } \\
\text { flaring of iliac crests laterally; } \\
\text { retarded bone age }\end{array}$ & $\begin{array}{l}\text { Posterior urethral valves; } \\
\text { hypospadias; undescended } \\
\text { testes }\end{array}$ & $\begin{array}{l}\text { Small for gestational age; } \\
\text { retarded growth and } \\
\text { development; low-set ears; } \\
\text { short lingual frenulum; } \\
\text { narrow trachea; cleft palate }\end{array}$ \\
\hline
\end{tabular}

one of them had pericentric inversion of chromosome number one; and the other had a normal karyotype. The seven cases reported by us represent four years of experience without specific survey. The association of ocular colobomata and congenital heart disease is thus felt to be nonrandom.

The aetiology of this association of colobomata and congenital heart disease is not known at present. Coloboma of the fundus, with or without involvement of the iris, at the typical position is due to failure of closure of the fetal fissure, which normally occurs in the sixth week of fetal life (Mann, 1964). The extent to which the cleft remains open determines which tissues of the eye manifest defects. Development of the iris normally begins in the latter part of the third month and is not completed until 8 months of fetal life (Mann, 1964). Thus, an adverse factor acting after the sixth week of fetal life may result in an isolated coloboma of the iris, without involvement of the ciliary body, retina or choroid. The critical period for the development of the heart is thought to be between 3 and 7 weeks of fetal life (Moore, 1973). It is possible that a noxious agent present in the critical period of time common to both the eye and the heart might result in malformation of these two organs. This critical time is probably before 7 weeks of fetal life.

Ocular colobomata are most frequently inherited as an autosomal dominant trait and rarely as an autosomal recessive (Waardenburg et al, 1961) or Xlinked recessive trait (Goldberg and McKusick, 1971). In the family of case 1 and case 2, the recessive form of transmission seems unlikely; because the probability of both unaffected, unrelated fathers being heterozygous is extremely small. The $\mathrm{X}$-linked disease mainly affects males and includes microphthalmos which was not present in our patients. Typical iris coloboma is almost always transmitted as an autosomal dominant trait. We assume that this is the situation in this family. Cataracts were also present in the mother and both children. There was no evidence of intrauterine 
PATIENTS WITH OCULAR COLOBOMATA, CONGENITAL HEART DISEASE,

\begin{tabular}{|c|c|c|c|}
\hline Reference & Sex & Eyes & Heart \\
\hline Rolando and Jemma (1959)* & $\mathbf{F}$ & $\begin{array}{l}\text { Colobomata of iris, retina, choroid, OU; } \\
\text { microcornea, OU; exotropia; nystagmus }\end{array}$ & Ventricular septal defect \\
\hline Angelman $(1961 \text {; case } 2)^{*}$ & $\mathbf{M}$ & Typical colobomata, iris, retina, choroid, OU & Patent ductus arteriosis \\
\hline Angelman $(1961 \text {; case } 3)^{*}$ & $\mathbf{F}$ & $\begin{array}{l}\text { Typical coloboma, iris and lens with thinning } \\
\text { of choroid and retina, OS; strabismus; } \\
\text { wide-set, prominent eyes }\end{array}$ & Pulmonary stenosis \\
\hline Edwards et al $(1961$; case 1$) \dagger$ & $\mathbf{M}$ & Typical coloboma, choroid, OD & Probable ventricular septal defect \\
\hline Edwards et al (1961; case 3$) \dagger$ & $\mathbf{M}$ & $\begin{array}{l}\text { Deep excavations, optic disc; bilateral } \\
\text { posterior staphylomata }\end{array}$ & Patent ductus arteriosus; right sided aorta \\
\hline Richards (1961)* & $\mathbf{M}$ & Ocular coloboma, OS & Probable ventricular septal defect \\
\hline Lele et al $(1965$; case 4$) \dagger$ & $\mathbf{M}$ & Typical colobomas, iris, retina, OD & Ventricular septal defect \\
\hline
\end{tabular}

* Karyotype not reported.

t Normal karyotype.

infections or galactosaemia. The cataracts appear to be a dominantly transmitted trait. It is uncertain whether or not the congenital heart disease, colobomata, and cataracts are inherited together as a single entity. The mother has a history of a heart murmur, but shows no evidence of congenital heart disease at present. However, $25 \%$ of ventricular septal defects present in infancy may undergo spontaneous closure in later life (Bloomfield, 1964). Thus there is a possibility that the mother may have had a form of congenital heart disease which is not now clinically evident. The fact that both sisters of different, unrelated, normal fathers have congenital heart disease suggests that the predisposition to the congenital heart disease also came from the mother.

The patients reported here and those in the literature (Rolando and Jemma, 1959; Angelman, 1961; Edwards et al, 1961; Richards, 1961; Lele et al, 1965) have a number of clinical features in common with patients having the cat eye syndrome. That condition, however, appears related to the presence of an extra acrocentric chromosome and involved individuals also have anal atresia (Schachenmann et al, 1965; Freedom and Gerald, 1973). Franklin and Parslow (1972) described two sisters with 'cat eye syndrome', who had normal karyotypes. Both had anal atresia and tetralogy of Fallot. One had a unilateral iris coloboma and the other had microphthalmos without an ocular coloboma. The parents of their patients were normal, in contrast to our patients, whose mother also had iris colobomata.

Ocular colobomata and congenital heart disease are frequently associated with abnormalities in other organ systems (Table I). The association of congenital heart disease with vertebral, anal, tracheal, oesophageal, renal, and limb anomalies has previously been reported (Quan and Smith, 1973). Of our seven cases, five had neurological problems, six had skeletal defects, and five had urogenital anomalies. These findings are in agreement with the cases reported in the literature, which are summarized in Table II. Therefore, the discovery of an ocular coloboma should alert the clinician to search for other abnormalities.

Dr Robert L. Kaufman was supported by USPHS Postgraduate Training Grant TO1 GM0511, the Ranken-Jordan Trust Fund and the James $H$. Woods Foundation. Dr Steven M. Podos was supported by grant NIH-NEI 5P01 EY00336.

\section{REFBRENCES}

Allerdice, P. W., Davis, J. G., Miller, O. J., Klinger, H. P., Warburton, D., Miller, D. A., Allen, F. H., Jr., Abrams, C. A. L., and McGilvray, E. (1969). The 13q - deletion syndrome. American fournal of Human Genetics, 21, 499-512.

Angelman, H. (1961). Syndrome of coloboma with multiple congenital abnormalities in infancy. British Medical fournal, 1, 1212-1214.

Bilchik, R. C., Zackai, E. H., Smith, M. E., and Williams, J. D. (1972). Anomalies with ring D chromosome. American fournal of Ophthalmology, 73, 83-89. 


\begin{tabular}{|c|c|c|c|}
\hline \multicolumn{4}{|c|}{ Associated Abnormalities } \\
\hline Neurological & Skeletal & Urogenital & Others \\
\hline- & - & $\begin{array}{l}\text { Double collecting system, left } \\
\text { kidney; pelvic ectopia, right } \\
\text { kidney }\end{array}$ & $\begin{array}{l}\text { Mother had viral hepatitis during } \\
\text { 1st-2nd months of pregnancy }\end{array}$ \\
\hline $\begin{array}{l}\text { Hydrocephalus; spasticity; } \\
\text { psychomotor retardation }\end{array}$ & $\begin{array}{l}\text { Talipes equinovarus, left foot; } \\
\text { hemivertebra }\end{array}$ & - & Right inguinal hernia \\
\hline - & - & - & $\begin{array}{l}\text { Retarded growth and } \\
\text { development; beaked nose; } \\
\text { cleft soft palate; cyanosis; } \\
\text { clubbing of fingers }\end{array}$ \\
\hline- & - & - & $\begin{array}{l}\text { Retarded growth and } \\
\text { development; micrognathia; } \\
\text { low-set ears }\end{array}$ \\
\hline $\begin{array}{l}\text { Abnormal EEG; right facial } \\
\text { paralysis }\end{array}$ & - & $\begin{array}{l}\text { Agenesis, right kidney and } \\
\text { ureter }\end{array}$ & $\begin{array}{l}\text { Retarded development; } \\
\text { micrognathia; high-arched } \\
\text { palate; low-set, anteriorly } \\
\text { rotated ears }\end{array}$ \\
\hline Mental retardation & Abnormal left fifth finger & - & $\begin{array}{l}\text { Suggestive webbing of neck; } \\
\text { small size }\end{array}$ \\
\hline- & - & - & Cleft palate \\
\hline
\end{tabular}

Bloomfield, D. K. (1964). The natural history of ventricular septal defect in patients surviving infancy. Circulation, 29, 914-955.

Bolk, L. (1904). Statistische mededeeling over het voorkomen van coloboma iridis. Nederlandsch Tijdschrift voor Geneeskunde, 40 (part 2), 1063-1064.

Conen, P. E., Erkman, B., and Metaxotou, C. (1966). The 'D' syndrome, report of 4 trisomic and one $D / D$ translocation case. American fournal of Diseases of Children, 111, 236-247.

Cullen, J. F. (1964). Ocular defects in thalidomide babies. British fournal of Ophthalmology, 48, 151-153.

Duke-Elder, W. S. (1940). Typical colobomata. In Textbook of Ophthalmology, vol. 2, pp. 1252-1256. C. V. Mosby, St Louis.

Edwards, J. H., Young, R. B., and Finlay, H. V. L. (1961). Coloboma with multiple congenital anomalies. British Medical fournal, 2, 586-587.

François, J. (1968a). Autosomal chromosome aberrations in ophthalmology. International Ophthalmology Clinics, 8, 839-910.

François, J. (1968b). Colobomatous malformations of the ocular globe. International Ophthalmology Clinics, 8, 797-816.

Franklin, R. C. and Parslow, M. I. (1972). The cat-eye syndrome, review and two further cases occurring in female siblings with normal chromosomes. Acta Paediatrica Scandinavica, 61, 581586.

Freedom, R. M. and Gerald, P. S. (1973). Congenital cardiac disease and the 'Cat Eye' syndrome. American fournal of Diseases of Children, 126, 16-18.

Gardiner, P. A. and Joseph, M. (1968). Eye defects in children with congenital heart lesions: A preliminary study. Developmental Medicine and Child Neurology, 10, 42-48.

Goldberg, M. F. and McKusick, V. A. (1971). X-linked colobomatous micro-ophthalmos and other congenital anomalies. American fournal of Ophthalmology, 71, 1128-1133.

Kaufman, R., Ho, C., Podos, S., Hartmann, A., and Hernandez, A. (1973). Familial occurrence of iris colobomas associated with congenital heart disease. American fournal of Human Genetics, 25 (No. 6), 39A.

Lee, C. S. N., Boyer, S. H., Bowen, P., Weatherall, D. J., Rosenblum, H., Clark, D. B., Duke, J. R., Liboro, C., Bias, W., and Borgaonkar; D. S. (1966). The Dl trisomy syndrome: three subjects with unequally advancing development. Bulletin of the fohns Hopkins Hospital, 118, 374-394.
Lele, K. P., Dent, T., and Delhanty, J. D. A. (1965). Chromosome studies in five cases of coloboma of the iris. Lancet, 1, 576-578.

MacMahon, B., McKeown, T., and Record, R. G. (1953). The incidence and life expectation of children with congenital heart disease. British Heart fournal, 15, 121-129.

Mann, I. (1964). The closure of the foetal fissure and the further differentiation of the optic cup. In The Development of the Human Eye, pp. 30-33. British Medical Association, London.

Moore, K. L. (1973). The Circulatory System. In The Developing Human; Clinically Oriented Embryology, pp. 117, 239-280. W. B. Saunders, Philadelphia.

Orbeli, D. J., Lurie, I. W., and Goroshenko, J. L. (1971). The syndrome associated with the partial D-monosomy. Humangenetik, 13, 296-308.

Polani, P. E. and Campbell, M. (1955). An aetiological study of congenital heart disease. Annals of Human Genetics, 19, 209-230.

Quan, L. and Smith, D. W. (1973). The VATER association: vertebral defects, anal atresia, fistula with esophageal atresia, radial and renal dysplasia: a spectrum of associated defects. Fournal of Pediatrics, 82, 104-107.

Richards, M. V. (1961). Coloboma with multiple congenital anomalies. British Medical fournal, 1, 1540.

Rolando, D. and Jemma, R. (1959). Su di una rara sindrome malformativa multipla. (Associazione di malformazioni oculari, cardiache e delle vie urinarie.) Pediatria, 67, 498-512.

Schachenmann, G., Schmid, W., Fraccaro, M., Mannini, A., Tiepolo, L., Perona, G. P., and Sartori, E. (1965). Chromosomes in coloboma and anal atresia. Lancet, 2, 290.

Waardenburg, P. J., Franceschetti, A., and Klein, D. (1961). Colobomas. In Genetics and Ophthalmology, vol. I, pp. 778-790. Royal Van Gorcum, Assen.

Warkany, J. (1971). Neurologic ocular and mental complications. In Congenital Malformations, Notes and Comments, p. 570. Year Book Medical Publishers, Chicago.

Warkany, J., Passarge, E., and Smith, L. B. (1966). Congenital malformations in autosomal trisomy syndromes. American fournal of Diseases of Children, 112, 502-517.

Weber, W. W., Mamunes, P., Day, R., and Miller, P. (1964). Trisomy 17-18 (E): Studies in long term survival with report of two autopsied cases. Pediatrics, 34, 533-541. 